\title{
Review
}

\section{Mitochondrial Dysfunction is a Converging Point of Multiple Pathological Pathways in Amyotrophic Lateral Sclerosis}

\author{
Ping Shi ${ }^{\mathrm{a}}$, Yanming Wei ${ }^{\mathrm{b}}$, Jiayu Zhang ${ }^{\mathrm{b}}$, Jozsef Gal ${ }^{\mathrm{b}}$ and Haining Zhu ${ }^{\mathrm{a}, \mathrm{b}, *}$ \\ ${ }^{a}$ Graduate Center for Toxicology, College of Medicine, University of Kentucky, Lexington, KY, USA \\ ${ }^{\mathrm{b}}$ Department of Molecular and Cellular Biochemistry, College of Medicine, University of Kentucky, Lexington, KY, \\ USA
}

Accepted 15 April 2010

\begin{abstract}
A better understanding of the etiology of amyotrophic lateral sclerosis (ALS) is needed to develop effective therapies for the treatment of this fatal neurodegenerative disease. Extensive studies have produced a general agreement that ALS is likely to be a multifactorial and multisystem disease. Many mechanisms have been postulated to be involved in the pathology of ALS, such as oxidative stress, glutamate excitotoxicity, mitochondrial damage, defective axonal transport, glia cell pathology, and aberrant RNA metabolism. Mitochondria have shown to be an early target in ALS pathogenesis and contribute to the disease progression. Morphological and functional defects in mitochondria were found in both human patients and ALS mice overexpressing mutant SOD1. Mutant SOD1 was found to be preferentially associated with mitochondria and subsequently impair mitochondrial function. Recent studies suggest that axonal transport of mitochondria along microtubules is disrupted in ALS. Furthermore, new evidence suggests that mitochondrial fission and fusion as well as mitophagy clearance may also be affected by mutant SOD1. These results also illustrate the critical importance of maintaining proper mitochondrial function in axons and neuromuscular junctions, supporting the emerging "dying-back" axonopathy model of ALS. In this review, we will discuss findings supporting that mitochondrial dysfunction is likely to be a converging point of multiple pathways underlying the ALS pathogenesis and progression.
\end{abstract}

Keywords: Amyotrophic lateral sclerosis, autophagy, axonal transport, mitochondrial dynamics, mitochondrial function, mutant SOD1

\section{INTRODUCTION}

Amyotrophic lateral sclerosis (ALS) is a progressive and fatal neurodegenerative disease characterized by preferential motor neuron death. Approximately 10$20 \%$ of the ALS cases are familial whereas the major-

* Correspondence to: Haining Zhu, Department of Molecular and Cellular Biochemistry, College of Medicine, University of Kentucky, 741 South Limestone, Lexington, Kentucky 40506, USA. Tel.: +1 859323 3643; E-mail: haining@uky.edu. ity of them are sporadic without family history. The copper-zinc superoxide dismutase (SOD1) gene was the first ALS gene discovered in 1993 and is the most prevailing gene accounting for approximately $20 \%$ of familial ALS cases (i.e., $\sim 2 \%$ of all ALS cases) [1, 2]. Mutations in other genes have also been found to cause various subsets of familial ALS, including a potential G-protein exchange factor ALS2 [3,4], vesicleassociated membrane protein B (VAPB) [5], senataxin [6], the p150 subunit of dynactin (DCTN1) [7], angiogenin [8], and the recently discovered RNA pro- 
cessing proteins TDP-43 [9,10] and FUS/TLS [11,12]. Studying the familial ALS gene mutations will help understand the etiology of ALS, particularly the potential mechanisms underlying both sporadic and familial ALS. Among all ALS-causing genes being studied, mutant SOD1-mediated familial ALS has been studied most extensively in the past decade. The field has reached a general agreement that mutant SOD1 can cause disruption to multiple cellular processes, which may collectively contribute to the disease pathogenesis. Although new insights are likely to be revealed in coming years studying the newly discovered ALS-causing RNA metabolism proteins TDP-43 and FUS/TLS, this review is focused on the mitochondrial dysfunction in the mutant SOD1-mediated familial ALS.

The mitochondrion is a critical organelle in aerobic cells executing multiple functions. Mitochondria are the primary site of ATP production, maintain calcium homeostasis, participate in calcium signaling, and regulate intrinsic apoptosis. The structure, position, and function of the mitochondria are regulated by mitochondrial biogenesis, fission and fusion, transport, and clearance [13]. Therefore, mitochondrial malfunction confers pleiotropic effects on the cells, especially neurons with an elevated susceptibility to aging and stress. Mitochondrial pathology is a key player among multiple working hypotheses in the study of ALS [2,14]. Mutant SOD1 has been reported to be associated with mitochondria, and the morphology, membrane potential, and bioenergetic function of mitochondria can consequently be impacted. More recent studies also support that axonal transport of mitochondria is disrupted by mutant SOD1 in ALS. Furthermore, mitochondrial dynamics and function can be disrupted when the axonal transport is compromised by mutant SOD1 in motor neurons. The above mechanisms are not mutually exclusive, but instead may form a vicious cycle that deteriorates mitochondria in motor neurons especially in the distal nerve terminals. These observations suggest that mitochondrial dysfunction is likely to be a converging point of multiple pathways underlying ALS pathogenesis and progression.

\section{MITOCHONDRIAL LOCALIZATION OF SOD1}

SOD1 is a soluble cytosolic protein that functions to dismutate reactive superoxide radicals into hydrogen peroxide and molecular oxygen. Besides the cytoplasm, wild-type (WT) SOD1 has been found in the nucleus [15], endoplasmic reticulum (ER) [16], and inter- membrane space (IMS) of mitochondria [17,18]. Depending on the subcellular localization, mutant SOD1 protein may exert compartment-specific toxicity. For instance, mutant SOD1 was found to accumulate inside the ER, form insoluble high molecular weight species, interact with the ER chaperone proteins, and induce ER stress within spinal motor neurons [16]. Other studies also showed that mutant SOD1 caused dysfunction of ER-associated degradation machinery and triggered ER stress, which could influence the progressive manifestations of familial ALS [19-21].

More interestingly, the ALS-related mutant SOD1 proteins have also been found in the IMS, matrix, and outer membrane of mitochondria [22-25]. Copper chaperone for SOD1 (CCS) is also partially localized in mitochondria [18] and assists in the entry and retention of SOD1 in mitochondria [26]. Increased localization of mutant SOD1 in mitochondria by CCS overexpression in the CCS/G93A-SOD1 double transgenic mice caused early mitochondrial pathology and accelerated the disease course [27]. A separate study found that the ALS-linked SOD1 mutants were selectively associated with spinal mitochondria and a fraction of them aggregated on the cytoplasmic surface of mitochondria in transgenic mutant SOD1 mice [28]. The study also showed that SDS-resistant aggregates functionally damaged mitochondria through either clogging import channels or inhibiting outer mitochondrial membrane components. It is likely that mutant SOD1 fails to fold properly and perturbs the physiological regulation of mitochondrial import and retention [25]. However, it remains unclear how mutant SOD1 becomes aggregated on the outer membrane or in the matrix of mitochondria. It is also unclear how mutant SOD1 is selectively recruited to spinal, but not liver, mitochondria [28].

Once associated with mitochondria, the mutant SOD1 is believed to cause multiple damages to mitochondria. An early event could be damage to the mitochondrial membrane leading to loss of mitochondrial membrane potential and swelling of the important organelle [29,30]. Potential consequences include impaired respiratory complex [31-33], disrupted redox homeostasis, and decreased ATP production [34]. Furthermore, calcium homeostasis can be disrupted [33, 35-37] and apoptosis may be activated [38-40]. Details of the above interrelated mechanisms underlying mutant SOD1 induced mitochondrial dysfunction will be discussed in the sections in the first half of this review. 


\section{ABNORMAL MITOCHONDRIAL MORPHOLOGY AND BIOENERGETICS IN ALS}

Early studies have shown degenerating mitochondrial vacuoles in axons and dendrites of motor neurons in presymptomatic mice expressing mutant SOD1 [29, $30,41,42]$. In addition, dense conglomerates of mitochondria in the anterior horn of lumbar spinal cord and proximal axons have been found in sporadic ALS patients $[43,44]$. Abnormal clustering of mitochondria was recently reported in motor axons in mutant SOD1 transgenic mice [45]. Extensive fragmentation of mitochondria was also reported in cultured NSC34 cells overexpressing mutant SOD1 [46,47]. A further study found that vacuolation of mitochondria in the spinal motor neurons of G93A transgenic mice was caused by expansion of the IMS and the outer mitochondrial membrane. The same study found that the degenerative vacuoles were bounded by mutant SOD1 that colocalized with mitochondrial outer membrane markers [48]. Besides alteration of mitochondrial morphology, damage to the mitochondrial membrane caused by mutant SOD1 can yield loss of mitochondrial membrane potential, disruption of mitochondrial respiratory chain activity $[31,32]$, and reduction in mitochondrial $\mathrm{Ca}^{2+}$ buffering capability [37]. The dysregulation in electron transfer chain complexes was observed in both G93A SOD1 transgenic mice and human ALS patients [31, 33].

\section{DISRUPTION OF CALCIUM HOMEOSTASIS IN ALS}

An important function of mitochondria is to buffer intracellular surges of $\mathrm{Ca}^{2+}$ in excitable cells such as neurons. In motor neurons, mitochondria play an important role in short-term handling of rapid cytosolic $\mathrm{Ca}^{2+}$ transients. $\mathrm{Ca}^{2+}$ is a ubiquitous second messenger and participates in many signaling pathways that are crucial for cell survival. Increased $\mathrm{Ca}^{2+}$ concentration and mitochondrial damage were found in ALS patients as well as animal and cellular ALS models [36, 37,49-51]. A significant decrease in mitochondrial $\mathrm{Ca}^{2+}$ loading capacity in brain and spinal cord, but not in liver, was observed in presymptomatic G93A mutant transgenic mice [50]. Elevated $\mathrm{Ca}^{2+}$ can induce reactive oxygen species and oxidative stress in primary motor neurons isolated from G93A transgenic mice [36]. Alternatively, $\mathrm{Ca}^{2+}$ mediated glutamate excitotoxicity might contribute to the mutant SOD1 toxicity in motor neurons. In addition, elevated local calcium levels can play a role in regulating axonal transport of mitochondria [52-54] (see details in the later section), providing a signaling circuit of the calcium buffering ability of mitochondria, calcium homeostasis, and mitochondrial distribution. Altogether, the mitochondrial dysfunction induced by mutant SOD1, disrupted calcium homeostasis, aberrant mitochondrial distribution, and excitotoxicity are likely to be interrelated mechanisms that collectively contribute to motor neuron degeneration in ALS.

\section{INTRINSIC APOPTOTIC PATHWAY MEDIATED BY MITOCHONDRIA IN ALS}

Mitochondria-mediated apoptosis was found to be involved in motor neuron degeneration in early studies of ALS. In G93A SOD1 transgenic mice, cytosolic release of cytochrome $c$ was observed [38-40], and levels of pro-apoptotic proteins Bad and Bax were increased while those of anti-apoptotic proteins $\mathrm{Bcl}-2$, Bcl-xL, and XIAP were decreased [55-57]. It has been proposed that mutant SOD1 can sequester anti-apoptotic protein $\mathrm{Bcl}-2$ [38], reduce mitochondrial membrane potential, and trigger cytochrome $c$ release from mitochondria [38-40]. Caspase-1 and caspase-3 were also found to be sequentially activated in motor neurons and astrocytes in G93A SOD1 mice as well as in G37R SOD1 and G85R SOD1 mice [58-60]. Strategies intervening in mitochondria-mediated apoptosis were demonstrated to be effective in G93A SOD1 mice: (a) intraventricular administration of minocycline, which inhibits cytochrome $c$ release from mitochondria, was shown to delay disease onset and extend survival [61]; (b) overexpression of anti-apoptotic protein Bcl-2 could delay activation of the caspases, attenuate neuron degeneration and delay disease onset and mortality [56, 62]; (c) intraventricular administration of a broad spectrum caspase inhibitor zVAD-fmk could delay disease onset and mortality [58]; and (d) the deletion of cyclophilin D, a component of the mitochondrial permeability transition pore, significantly delayed the disease onset and extended the lifespan of ALS mice expressing high and low levels of G93A mutant SOD1 [63]. However, the clinical trials based on the above apoptosisinhibiting approaches (e.g., minocycline) failed in human ALS patients [64].

Gould and colleagues crossed the mutant SOD1 transgenic mice with Bax knockout mice and showed 
that neuromuscular denervation and mitochondrial vacuolization persisted in the absence of apoptotic death of motor neuron cell bodies in the double mutant mice [65]. Neuromuscular denervation was observed to begin long before the activation of apoptotic proteins, and Bax deficiency delayed the onset of neuromuscular denervation. Motor neurons exhibited mitochondrial abnormalities at the innervated neuromuscular junction at the onset of neuromuscular denervation. In addition, presynaptic terminals of motor neurons accumulated high levels of mutant SOD1 before the axons were withdrawn from the neuromuscular junction. A separate study showed denervation of $40 \%$ of neuromuscular junctions in pre-symptomatic G93A SOD1 transgenic mice (47 days), $60 \%$ loss of ventral root axons in 80 days old G93A mice (immediately prior to onset), and significant motor neuron death until 100 days old (post-symptomatic) [66]. The results from these studies support the "dying back" hypothesis that clinical symptoms in the G93A SOD1 mice result from damages to the distal motor axon rather than the activation of the cell death pathway in cell bodies. Furthermore, the results suggest that local mitochondrial changes in distal axons may represent a triggering mechanism for axonal degeneration and denervation. The findings inspired more careful studies of mitochondrial abnormalities in ALS with respect to the subcellular localization of such changes as well as the transport and dynamics of mitochondria. The findings and implications of mitochondrial transport and dynamics in the context of ALS are discussed below.

\section{DISRUPTION OF AXONAL TRANSPORT IN ALS}

Neurons have extensive dendritic arbors and axonal processes that can extend far from the soma. Transport of materials (proteins and organelles) between the cell body and neuronal processes is crucial to signal transduction and neuronal survival. Disruption of slow axonal transport of the cytoskeleton is one of the earliest pathological events in mutant SOD1 mice [67,68]. Fast axonal transport mediated by kinesin and dynein motor complexes is responsible for transporting membranebound organelles (e.g., mitochondria) to maintain axonal and synaptic function. Mutations in the anterograde transport motor protein kinesin (KIF5A) can cause spastic paraplegia [69] and mutations in the retrograde motor complex dynein-dynactin cause motor neuron degeneration in humans [70] and mice [71,72].
Mouse strains carrying various dynein or dynactin mutations also showed retrograde transport impairment and motor neuron degeneration [72-76]. Decreased kinesin-mediated (anterograde) and dynein-mediated (retrograde) axonal transport have been observed both in ALS patients and in transgenic animal models [67, 77-82]. More intriguingly, crossing of G93A SOD1 ALS mice with different mouse strains carrying dynein or dynactin mutations resulted in various degrees of protection in the double mutant mice $[73,74,83,84]$. Nevertheless, the results strongly support that axonal transport is likely a critical component in ALS disease etiology.

The precise mechanisms by which axonal transport is affected by mutant SOD1 in ALS have yet to be established. In the last few years, ALS-related mutant SOD1 proteins have been shown to associate with both the anterograde motor kinesin-2 complex via kinesinassociated protein 3 (KAP3) and the retrograde motor dynein-dynactin complex, providing potential molecular mechanisms how mutant SOD1 might interfere with axonal transport [85-87]. Most recently, a genomewide single nucleotide polymorphism analysis in a set of 1821 sporadic ALS cases and 2258 controls from the United States and Europe revealed that a variant within the KAP3 gene was associated with decreased KAP3 expression and increased survival in sporadic ALS [88]. Examination of the literature revealed a report showing increased expression of $K A P 3$ in mutant SOD1 transgenic mice [89]. These findings provide an emerging concept that alterations of axonal transport might be involved in both familial and sporadic ALS.

It also remains unclear how impairment of axonal transport cause motor neuron dysfunction and degeneration. Some transport cargos such as neurotrophic factors, signaling molecules, and mitochondria are obvious targets. Perlson and collaborators recently showed the inhibition of retrograde survival signaling (P-Trk and p-Erk1/2) and increase of stress signaling (P-JNK, caspase- 8 and $\mathrm{p} 75^{N T R}$ ) in the G93A transgenic mice [90], indicating that suppression of dynein-mediated retrograde transport can produce cargo-dependent insults to motor neurons in ALS. Several studies also demonstrated that p38 stress-activated kinase was activated and phosphorylated neurofilaments (NFM and NFH) in G93A transgenic mice [91, 92]. In addition, p38 has been shown to be involved in regulating fast axonal transport including transport of mitochondria [93,94]. Additional studies are needed to elucidate how axonal transport is perturbed and how it subsequently contributes to the disease. 


\section{AXONAL TRANSPORT OF MITOCHONDRIA AND ITS REGULATION}

Axonal transport of mitochondria is essential to neurons due to their extensive processes between the soma and the synaptic sites at the cell periphery [95]. Mitochondria are highly dynamic and respond to momentto-moment changes in the energy demands of the cell [96]. In neurons, mitochondria frequently accumulate in axonal terminals for the high demand of ATP and $\mathrm{Ca}^{2+}$ influx at synapses $[97,98]$. In hippocampal neurons, mitochondria dynamically relocated into dendritic protrusions in response to synaptic excitation and facilitated synaptogenesis and spine formation [99]. The bidirectional transport of mitochondria mainly depends on two motor protein families: the kinesin superfamily proteins in the anterograde transport and the dynein protein complex in the retrograde transport. Disruption of kinesin heavy chain KIF5B causes perinuclear clustering of mitochondria in mouse neurons, indicating that KIF5B is essential for mitochondrial dispersion [100]. In addition, other kinesin superfamily members KIF1B and KLC3 are also implicated in anterograde transport of mitochondria [101,102]. Dynein is important not only for axonal retrograde transport of mitochondria but also for mitochondrial fission [103].

The precise mechanisms that regulate the kinesin and dynein motor complexes and their attachment to the organelles are yet to be fully understood [95]. One mechanism by which mitochondria are attached to kinesin has been described. Milton is an adaptor protein interacting with both kinesin heavy chain (KHC) and the mitochondrial Rho GTPase protein Miro and recruits mitochondria to the kinesin motor for transport [52,104-107]. The interaction between Milton and KHC is independent of kinesin light chain (KLC). Miro mutants in Drosophila cause enrichment of mitochondria in neuronal somata and reduction in neuropil [106]. GTPase defective mutants of Miro resulted in the aggregation of mitochondria and the constitutively active Miro induced apoptotic cell death [107]. The C-terminal transmembrane domain within Miro is required for mitochondrial outer membrane targeting. The N-terminus within Miro is responsible for binding with the kinesin-interacting protein GABA-A receptor-interacting factor 1 (GRIF-1) and O-linked Nacetylglucosamine transferase interacting protein 106 (OIP106), linking mitochondria to kinesin-mediated axonal transport [108-110].

Miro contains two $\mathrm{Ca}^{2+}$-binding EF-hand motifs, providing a calcium-responsive mechanism to regulate mitochondrial transport. $\mathrm{Ca}^{2+}$ binding to the EF-hand motif of Miro can promote direct binding of Miro to KHC rather than via Milton and prevent the attachment of KHC to microtubules [52]. In response to excitation, an influx of $\mathrm{Ca}^{2+}$ in both pre- and post-synaptic cytosol will consequently inhibit mitochondrial transport. The locally arrested mitochondria are then able to provide more ATP and to buffer high $\mathrm{Ca}^{2+}$ to avoid overexcitement. Mitochondria subsequently move away when the local $\mathrm{Ca}^{2+}$ concentration returns to normal and ATP is supplied [53,54]. This provides a mechanism for responding to local calcium homeostasis and energy demand.

Neurotrophic factors, which are critical to neuronal differentiation and survival and axonal growth and maintenance, can also regulate axonal transport of mitochondria. For instance, nerve growth factor has been shown to regulate the motility and distribution of axonal mitochondria and cause the local accumulation of mitochondria in cultured primary neurons $[111,112]$.

\section{IMPAIRED AXONAL TRANSPORT OF MITOCHONDRIA IN ALS}

Impairment of mitochondrial transport has been reported in several neurodegenerative diseases including Huntington's disease [113] and Parkinson's disease [114] as well as ALS [95,115-118]. One study showed that mitochondrial transport was reduced in the anterograde direction in motor neurons and cortical neurons [115]. However, another study showed that both anterograde and retrograde transport of mitochondria were altered by mutant SOD1 in differentiated NSC34 cells expressing mitochondria-targeted SOD1 [116,117]. In addition, mutant SOD1 also caused mitochondrial fragmentation and impaired mitochondrial dynamics in the studies $[116,117]$.

Although the mechanism by which mutant SOD1 disrupts axonal transport of mitochondria is not completely understood, several possible scenarios are illustrated in Fig. 1. First, mitochondrial transport and membrane potential are correlated [119]. As discussed earlier, mutant SOD1 can cause a partial loss of mitochondrial membrane potential, and thus can change axonal transport of mitochondria. Second, the elevated local $\mathrm{Ca}^{2+}$ concentration induced by decreased mitochondrial buffering capability can promote detachment of KHC from microtubule [52-54]. Third, various kinases have been reported to be activated by pathogenic proteins implicated in different neurodegenerative dis- 


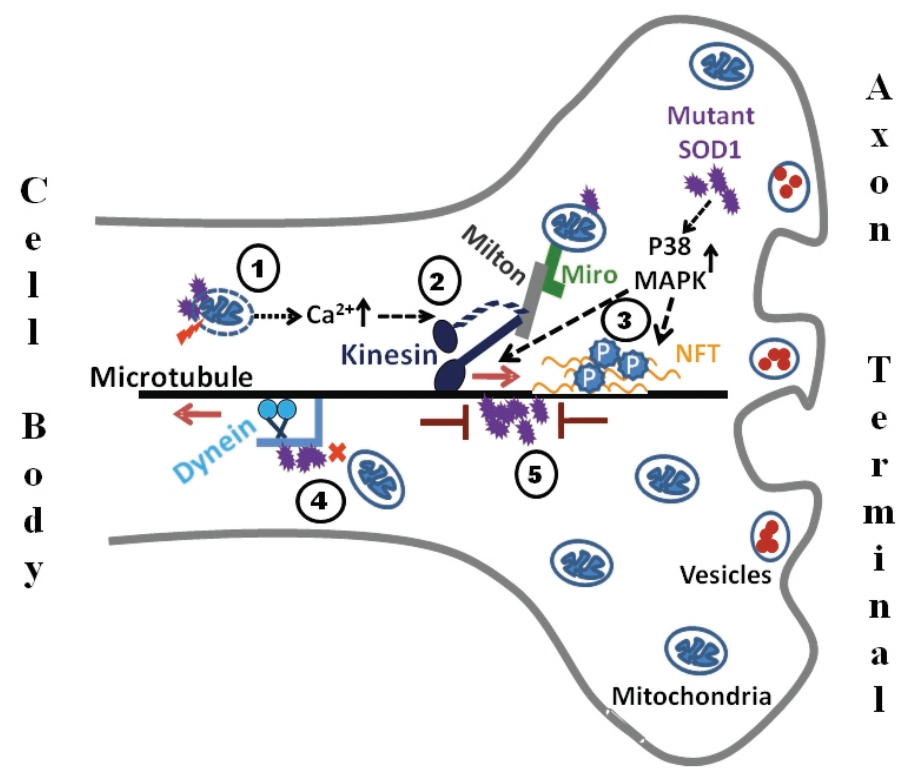

Fig. 1. Potential mechanisms for the involvement of mitochondrial dysfunction in ALS. Several possible mechanisms by which mutant SOD1 can cause impairment of axonal transport and abnormalities in mitochondrial function and dynamics are illustrated. (1) Disturbed mitochondrial membrane potential can impact mitochondrial transport. (2) Elevated $\mathrm{Ca}^{2+}$ levels can prevent kinesin from binding to microtubules and lead to decreased anterograde axonal transport. (3) The stress-responsive p38 MAP kinase pathway is activated and results in phosphorylated neurofilaments and their accumulation along axons. In addition, kinesin heavy chain and kinesin light chain can be phosphorylated by various kinases and anterograde transport could be affected. (4) Mutant SOD1 can interact with the dynein-dynactin complex and may result in impairment of retrograde transport. (5) Aggregation of mutant SOD1 along microtubules may interfere with both anterograde and retrograde transport like a blockade. Impairment of axonal transport of mitochondria would likely perturb mitochondrial dynamics. )

eases. The stress-responsive p38 MAP kinase pathway was reported to be activated in mutant SOD1 transgenic mice [91,120]. The activated kinases can phosphorylate KHC or KLC and affect anterograde transport [93,121-124]. Alternatively, activated MAP kinase can also phosphorylate neurofilaments and lead to their accumulation in axons $[91,92]$. The activation of MAP kinase potentially provides a connection between mutant SOD1 and kinesin-mediated axonal transport. Fourth, the aberrant interaction between mutant SOD1 and the dynein-dynactin complex could also disrupt retrograde transport of mitochondria $[85,86]$. Fifth, mutant SOD1 aggregation along microtubules may interfere with both anterograde and retrograde transport like blockades along highways. In addition, anterograde and retrograde transport are interrelated and highly regulated, thus it is not surprising that disruption of the transport in one direction would affect the transport in the other direction.

It is noted that the effect of mutant SOD1 on the axonal transport of different cargos could be distinct. It was recently reported that the retrograde survival signaling was suppressed while the transport of stress signaling was increased in the G93A transgenic mice [90]. The axonal transport of mitochondria was shown to be impaired in either the anterograde direction [115] or in both anterograde and retrograde directions [117]. Another study showed that mutant SOD1 interacted with the kinesin-2 complex via kinesin-associated protein 3 (KAP3) and impaired anterograde transport of choline acetyltransferase [87]. Will the axonal transport of mitochondria and of choline acetyltransferase be affected in the same fashion in the presence of mutant SOD1? It is conceivable that transport of different organelles, cargos, or signals can be differentially altered in the presence of the ALS-linked SOD1 mutants. Future studies are needed to clarify how axonal transport of mitochondria is altered in ALS and to understand the mechanisms.

\section{MITOCHONDRIAL DYNAMICS (FISSION, FUSION, AND MITOPHAGY) IN ALS}

Mitochondria maintain their proper morphology and function through fusion, fission, and clearance by autophagy (mitophagy). Disrupting the balance of the processes would result in mitochondrial fragmentation, elongation, or aggregation [125]. It is logical to spec- 
ulate that mitochondrial morphology, metabolic function, membrane potential, axonal transport, and fission and fusion are highly inter-dependent.

In mammalian cells, mitochondria migrate along microtubules, encounter each other, and form a large network of long interconnected tubules. The fusion machinery includes Mfn1, Mfn2, and OPA1. Mfn1 and Mfn2 belong to the large GTPase family and localize to the mitochondrial outer membrane. OPA1 is a dynamin family GTPase and localizes within the mitochondrial intermembrane space. Mfn1 and Mfn2 deletion leads to loss of mitochondrial fusion, high fragmentation, and correspondingly no mitochondrial tubules. In addition, Mfn1 and Mfn2 deletion results in severe cellular defects, including widespread heterogeneity of mitochondrial membrane potential and decreased cellular respiration [126]. In humans, mutations in Mfn2 cause Charcot-Marie-Tooth neuropathy type $2 \mathrm{~A}$ and mutations in OPA1 cause the most common form of hereditary optic atrophy $[127,128]$. On the other hand, the components of mitochondrial fission machinery in mammals include Drp1 and Fis1. Dominant-negative mutants of Drp1 inhibit mitochondrial division and result in highly interconnected mitochondrial tubules [129]. Overexpression of Fis1 leads to mitochondrial fragmentation, release of cytochrome $c$, and ultimately apoptosis [130].

Abnormal mitochondrial clustering and fragmentation $[43,44,46,47,131]$ and altered mitochondrial transport $[115,117,132]$ are highly suggestive that mitochondrial dynamics may be influenced in the presence of mutant SOD1. A recent study showed mitochondrial fragmentation, impaired mitochondrial dynamics, and decreased density of mitochondria along neurites in differentiated NSC34 cells expressing mutant SOD1 [117]. Another study also showed that mutant SOD1 induced an extensive fragmentation of the mitochondrial network in NSC34 cells but not in other nonmotor neuron cell lines [46]. Changes in mitochondrial dynamics have also been found in other neurodegenerative diseases such as Alzheimer's disease (AD) [133135]. The results provided evidence that $\mathrm{A} \beta \mathrm{PP}$ mutant can cause an imbalance of mitochondrial fission and fusion likely through Dlp1, OPA1, and Fis1 proteins. Unlike in $\mathrm{AD}$, little is known regarding the molecular mechanism by which mutant SOD1 induces such defects in mitochondrial dynamics in ALS.

Mitochondrial dynamics is also closely related to apoptosis regulation and calcium homeostasis. During apoptosis, the dynamic balance of mitochondrial fusion and fission is altered, which leads to an extensive fragmentation of the mitochondria and release of proapoptotic factors $[136,137]$. Compared to normal interconnected mitochondrial network, fragmented mitochondria have lower $\mathrm{Ca}^{2+}$ buffering capacity and therefore probably cause selective death of motor neurons in ALS [138]. Thus, defects in mitochondrial fission and fusion can result in the malfunction of mitochondria.

Mitochondria clearance is believed to be accomplished by the autophagic degradation pathway, which is called mitophagy. Recent evidence showed that the mitochondrial protein Nix was a selective autophagy receptor by binding to LC3/GABARAP proteins that are required for autophagosome formation. Ablation of the Nix:LC3/GABARAP interaction suppressed mitochondrial clearance in maturing murine reticulocytes [139]. Mitophagy has been implicated in Parkinson's disease mediated by PINK1 and Parkin [13,140, 141]. This decreased mitochondrial clearance could cause the accumulation of defective and damaged mitochondria and ultimately lead to neurodegenerative diseases.

\section{AXONOPATHY MODEL OF ALS}

A "dying-back" axonopathy hypothesis of ALS is emerging in the field. Recent studies provide convincing evidence that denervation of motor neurons from muscles occurs in early stage of the disease pathogenesis prior to clinical symptoms in mutant SOD1 transgenic animals [65,66,82,142-144]. Interestingly, transgenic mice with muscular overexpression of uncoupling protein 1 (UCP1), which only caused mitochondrial defects in muscles, displayed age-dependent deterioration of neuromuscular junctions and subsequent motor neuron pathology [145]. The results are supportive of the notion that the distal pathology at neuromuscular junction can contribute to motor neuron degeneration in ALS. The results also illustrate the critical importance of proper function of mitochondria at both the presynaptic and postsynaptic compartments of the neuromuscular junction. As discussed earlier, mutant SOD1 may interfere with the mitochondrial function via multiple mechanisms, particularly via impairment of mitochondrial transport and dynamics. Thus, maintaining appropriate population of properly functioning mitochondria in distal axons could provide a critical therapeutic avenue for potential ALS treatment. 


\section{CELL AUTONOMOUS OR NOT?}

Another critical notion is that multiple cell types may contribute to the disease although motor neurons are the primarily affected cells in ALS (see review [146]). Multiple studies showed that neuron specific expression of mutant SOD1 was insufficient to produce ALS phenotypes in transgenic mice [147,148]. Further studies using chimeric mice with a mixture of normal and mutant SOD1-expressing cells [149] or transgenic mice carrying a cell-specific deletable mutant SOD1 gene [150-153] suggest that disease onset and progression may be influenced by mutant SOD1 expression in different cell types including motor neurons, microglia, astrocytes, and Schwann cells. Similar non-cell autonomous effects were also observed with primary and embryonic stem cell-derived motor neurons [154-156]. However, another study suggested that high expression of mutant SOD1 in neurons was sufficient to cause late onset disease [157]. Moreover, recent studies showed that expression of mutant SOD1 in muscles could also produce phenotypes reminiscent of ALS in transgenic mice $[158,159]$. These studies, which may appear conflicting, suggest that both cell-autonomous and noncell-autonomous processes may contribute to mutant SOD1 mediated motor neuron degeneration. It is likely that these two types of processes may differentially contribute to the disease onset and progression. The contribution of mitochondria in the cell-autonomous and non-cell-autonomous processes has yet to be better understood.

\section{CONCLUDING REMARKS}

It is believed that alterations in multiple pathways in multiple cell types can contribute to ALS pathogenesis and progression. Mitochondrial dysfunction plays a critical role in the pathogenesis of mutant SOD1 mediated familial ALS. Various aspects of the underlying mechanisms as well as functional consequences of mitochondrial dysfunction are discussed in this review. They include association of mutant SOD1 aggregates with mitochondria, abnormal mitochondrial morphology, impaired mitochondrial bioenergetics and degradation through autophagy, loss of mitochondrial membrane potential, reduced mitochondrial calcium buffering capacity and disrupted calcium homeostasis, impaired axonal transport of mitochondria, and potential imbalance of mitochondrial fission and fusion. In fact, many of the events can be cause for and consequence of each other and they create a vicious cycle that results in motor axon denervation and ultimately motor neuron degeneration in ALS.

It is evidently critical to determine the very first event induced by mutant SOD1 and devise a strategy to stop or delay it before the cycle becomes unstoppable. Misfolding of mutant SOD1 due to the intrinsic structural properties of the mutation is probably the first event. The impairment of axonal transport by misfolded mutant SOD1 is likely the immediate next event. The mitochondrial abnormalities can be secondary effects caused by compromised axonal transport as discussed in the review. This hypothesis would explain the accumulation of dysfunctional mitochondria in distal axon terminals and the axon degeneration that were observed in very early stage of presymptomatic ALS mice. This speculation is supportive of the "dying back" axonopathy model that is emerging in the ALS field. It is also essential to study the mechanisms in the context of each other to understand the crosstalk among the events so that potential therapeutic strategies may be designed to tackle multiple pathways simultaneously.

\section{ACKNOWLEDGMENTS}

The authors' research was in part supported by the NIH grants R01NS049126 and R21AG032567 to HZ. The support from NIH/NCRR Center of Biomedical Research Excellence in the Molecular Basis of Human Disease (COBRE, P20RR020171) is acknowledged.

Authors' disclosures available online (http://www.jalz.com/disclosures/view.php?id=421).

\section{REFERENCES}

[1] Rosen DR, Siddique T, Patterson D, Figlewicz DA, Sapp P, Hentati A, Donaldson D, Goto J, O'Regan JP, Deng HX, et al. (1993) Mutations in $\mathrm{Cu} / \mathrm{Zn}$ superoxide dismutase gene are associated with familial amyotrophic lateral sclerosis. Nature 362, 59-62.

[2] Bruijn LI, Miller TM, Cleveland DW (2004) Unraveling the mechanisms involved in motor neuron degeneration in ALS. Annu Rev Neurosci 27, 723-749.

[3] Yang Y, Hentati A, Deng HX, Dabbagh O, Sasaki T, Hirano M, Hung WY, Ouahchi K, Yan J, Azim AC, Cole N, Gascon G, Yagmour A, Ben-Hamida M, Pericak-Vance M, Hentati F, Siddique $\mathrm{T}$ (2001) The gene encoding alsin, a protein with three guanine-nucleotide exchange factor domains, is mutated in a form of recessive amyotrophic lateral sclerosis. Nat Genet 29, 160-165. 
[4] Hadano S, Hand CK, Osuga H, Yanagisawa Y, Otomo A, Devon RS, Miyamoto N, Showguchi-Miyata J, Okada Y, Singaraja R, Figlewicz DA, Kwiatkowski T, Hosler BA, Sagie T, Skaug J, Nasir J, Brown RH, Jr., Scherer SW, Rouleau GA, Hayden MR, Ikeda JE (2001) A gene encoding a putative GTPase regulator is mutated in familial amyotrophic lateral sclerosis 2. Nat Genet 29, 166-173.

[5] Nishimura AL, Mitne-Neto M, Silva HCA, Richieri-Costa A, Middleton S, Cascio D, Kok F, Oliveira JRM, Gillingwater T, Webb J, Skehel P, Zatz M (2004) A mutation in the vesicle-trafficking protein VAPB causes late-onset spinal muscular atrophy and amyotrophic lateral sclerosis. Am J Human Genet 75, 822-831.

[6] Chen Y-Z, Bennett CL, Huynh HM, Blair IP, Puls I, Irobi J, Dierick I, Abel A, Kennerson ML, Rabin BA, Nicholson GA, Auer-Grumbach M, Wagner K, De Jonghe P, Griffin JW, Fischbeck KH, Timmerman V, Cornblath DR, Chance PF (2004) DNA/RNA helicase gene mutations in a form of juvenile amyotrophic lateral sclerosis (ALS4). Am J Human Genet 74, 1128-1135.

[7] Munch C, Sedlmeier R, Meyer T, Homberg V, Sperfeld AD, Kurt A, Prudlo J, Peraus G, Hanemann CO, Stumm G, Ludolph AC (2004) Point mutations of the p150 subunit of dynactin (DCTN1) gene in ALS. Neurology 63, 724-726.

[8] Greenway MJ, Andersen PM, Russ C, Ennis S, Cashman S, Donaghy C, Patterson V, Swingler R, Kieran D, Prehn J, Morrison KE, Green A, Acharya KR, Brown RH, Jr., Hardiman O (2006) ANG mutations segregate with familial and 'sporadic' amyotrophic lateral sclerosis. Nat Genet 38, 411-413.

[9] Kabashi E, Valdmanis PN, Dion P, Spiegelman D, McConkey BJ, Vande Velde C, Bouchard JP, Lacomblez L, Pochigaeva K, Salachas F, Pradat PF, Camu W, Meininger V, Dupre N, Rouleau GA (2008) TARDBP mutations in individuals with sporadic and familial amyotrophic lateral sclerosis. Nat Genet 40, 572-574.

[10] Sreedharan J, Blair IP, Tripathi VB, Hu X, Vance C, Rogelj B, Ackerley S, Durnall JC, Williams KL, Buratti E, Baralle F, de Belleroche J, Mitchell JD, Leigh PN, Al-Chalabi A, Miller CC, Nicholson G, Shaw CE (2008) TDP-43 mutations in familial and sporadic amyotrophic lateral sclerosis. Science 319, 1668-1672.

[11] Vance C, Rogelj B, Hortobagyi T, De Vos KJ, Nishimura AL, Sreedharan J, Hu X, Smith B, Ruddy D, Wright P, Ganesalingam J, Williams KL, Tripathi V, Al-Saraj S, Al-Chalabi A, Leigh PN, Blair IP, Nicholson G, de Belleroche J, Gallo JM, Miller CC, Shaw CE (2009) Mutations in FUS, an RNA processing protein, cause familial amyotrophic lateral sclerosis type 6. Science 323, 1208-1211.

[12] Kwiatkowski TJ, Jr., Bosco DA, Leclerc AL, Tamrazian E, Vanderburg CR, Russ C, Davis A, Gilchrist J, Kasarskis EJ, Munsat T, Valdmanis P, Rouleau GA, Hosler BA, Cortelli P, de Jong PJ, Yoshinaga Y, Haines JL, Pericak-Vance MA, Yan J, Ticozzi N, Siddique T, McKenna-Yasek D, Sapp PC, Horvitz HR, Landers JE, Brown RH, Jr. (2009) Mutations in the FUS/TLS gene on chromosome 16 cause familial amyotrophic lateral sclerosis. Science 323, 1205-1208.

[13] Chu CT (2010) Tickled PINK1: mitochondrial homeostasis and autophagy in recessive Parkinsonism. Biochim Biophys Acta 1802, 20-28.

[14] Manfredi G, Xu Z (2005) Mitochondrial dysfunction and its role in motor neuron degeneration in ALS. Mitochondrion 5, 77-87.

[15] Crapo JD, Oury T, Rabouille C, Slot JW, Chang LY (1992) Copper,zinc superoxide dismutase is primarily a cytosolic protein in human cells. Proc Natl Acad Sci U S A 89, 1040510409.

[16] Kikuchi H, Almer G, Yamashita S, Guegan C, Nagai M, Xu Z, Sosunov AA, McKhann GM, 2nd, Przedborski S (2006) Spinal cord endoplasmic reticulum stress associated with a microsomal accumulation of mutant superoxide dismutase-1 in an ALS model. Proc Natl Acad Sci U S A 103, 6025-6030.

[17] Okado-Matsumoto A, Fridovich I (2001) Subcellular distribution of superoxide dismutases (SOD) in rat liver: $\mathrm{Cu}, \mathrm{Zn}-$ SOD in mitochondria. J Biol Chem 276, 38388-38393.

[18] Sturtz LA, Diekert K, Jensen LT, Lill R, Culotta VC (2001) A fraction of yeast $\mathrm{Cu}, \mathrm{Zn}$-superoxide dismutase and its metallochaperone, CCS, localize to the intermembrane space of mitochondria. A physiological role for SOD1 in guarding against mitochondrial oxidative damage. J Biol Chem 276, 38084-38089.

[19] Atkin JD, Farg MA, Turner BJ, Tomas D, Lysaght JA, Nunan J, Rembach A, Nagley P, Beart PM, Cheema SS, Horne MK (2006) Induction of the unfolded protein response in familial amyotrophic lateral sclerosis and association of proteindisulfide isomerase with superoxide dismutase 1. J Biol Chem 281, 30152-30165.

[20] Nishitoh H, Kadowaki H, Nagai A, Maruyama T, Yokota T, Fukutomi H, Noguchi T, Matsuzawa A, Takeda K, Ichijo H (2008) ALS-linked mutant SOD1 induces ER stress- and ASK1-dependent motor neuron death by targeting Derlin-1. Genes Dev 22, 1451-1464.

[21] Saxena S, Cabuy E, Caroni P (2009) A role for motoneuron subtype-selective ER stress in disease manifestations of FALS mice. Nat Neurosci 12, 627-636.

[22] Higgins CM, Jung C, Ding H, Xu Z (2002) Mutant Cu, Zn superoxide dismutase that causes motoneuron degeneration is present in mitochondria in the CNS. J Neurosci 22, RC215.

[23] Vijayvergiya C, Beal MF, Buck J, Manfredi G (2005) Mutant superoxide dismutase 1 forms aggregates in the brain mitochondrial matrix of amyotrophic lateral sclerosis mice. J Neurosci 25, 2463-2470.

[24] Vande Velde C, Miller TM, Cashman NR, Cleveland DW (2008) Selective association of misfolded ALS-linked mutant SOD1 with the cytoplasmic face of mitochondria. Proc Natl Acad Sci U S A 105, 4022-4027.

[25] Kawamata H, Manfredi G (2008) Different regulation of wild-type and mutant $\mathrm{Cu}, \mathrm{Zn}$ superoxide dismutase localization in mammalian mitochondria. Hum Mol Genet 17, 33033317.

[26] Field LS, Furukawa Y, O'Halloran TV, Culotta VC (2003) Factors controlling the uptake of yeast copper/zinc superoxide dismutase into mitochondria. J Biol Chem 278, 2805228059. .

[27] Son M, Puttaparthi K, Kawamata H, Rajendran B, Boyer PJ, Manfredi G, Elliott JL (2007) Overexpression of CCS in G93A-SOD1 mice leads to accelerated neurological deficits with severe mitochondrial pathology. Proc Natl Acad Sci U S A 104, 6072-6077.

[28] Liu J, Lillo C, Jonsson PA, Vande Velde C, Ward CM, Miller TM, Subramaniam JR, Rothstein JD, Marklund S, Andersen PM, Brannstrom T, Gredal O, Wong PC, Williams DS, Cleveland DW (2004) Toxicity of familial ALS-linked SOD1 mutants from selective recruitment to spinal mitochondria. Neuron 43, 5-17.

[29] Wong PC, Pardo CA, Borchelt DR, Lee MK, Copeland NG, Jenkins NA, Sisodia SS, Cleveland DW, Price DL (1995) An adverse property of a familial ALS-linked SOD1 mutation causes motor neuron disease characterized by vacuolar deg- 
eneration of mitochondria. Neuron 14, 1105-1116.

[30] Kong J, Xu Z (1998) Massive mitochondrial degeneration in motor neurons triggers the onset of amyotrophic lateral sclerosis in mice expressing a mutant SOD1. J Neurosci 18, 3241-3250.

[31] Borthwick GM, Johnson MA, Ince PG, Shaw PJ, Turnbull DM (1999) Mitochondrial enzyme activity in amyotrophic lateral sclerosis: implications for the role of mitochondria in neuronal cell death. Ann Neurol 46, 787-790.

[32] Jung C, Higgins CM, Xu Z (2002) A quantitative histochemical assay for activities of mitochondrial electron transport chain complexes in mouse spinal cord sections. $J$ Neurosci Methods 114, 165-172.

[33] Bowling AC, Schulz JB, Brown RH, Jr., Beal MF (1993) Superoxide dismutase activity, oxidative damage, and mitochondrial energy metabolism in familial and sporadic amyotrophic lateral sclerosis. J Neurochem 61, 2322-2325.

[34] Ferri A, Cozzolino M, Crosio C, Nencini M, Casciati A, Gralla EB, Rotilio G, Valentine JS, Carri MT (2006) Familial ALS-superoxide dismutases associate with mitochondria and shift their redox potentials. Proc Natl Acad Sci U S A 103, 13860-13865

[35] Krieger C, Lanius RA, Pelech SL, Shaw CA (1996) Amyotrophic lateral sclerosis: the involvement of intracellular $\mathrm{Ca} 2+$ and protein kinase C. Trends Pharmacol Sci 17, 114120.

[36] Kruman, II, Pedersen WA, Springer JE, Mattson MP (1999) ALS-linked $\mathrm{Cu} / \mathrm{Zn}$-SOD mutation increases vulnerability of motor neurons to excitotoxicity by a mechanism involving increased oxidative stress and perturbed calcium homeostasis. Exp Neurol 160, 28-39.

[37] Carri MT, Ferri A, Battistoni A, Famhy L, Gabbianelli R, Poccia F, Rotilio G (1997) Expression of a $\mathrm{Cu}, \mathrm{Zn}$ superoxide dismutase typical of familial amyotrophic lateral sclerosis induces mitochondrial alteration and increase of cytosolic $\mathrm{Ca} 2+$ concentration in transfected neuroblastoma SH-SY5Y cells. FEBS Lett 414, 365-368.

[38] Pasinelli P, Belford ME, Lennon N, Bacskai BJ, Hyman BT, Trotti D, Brown RH, Jr. (2004) Amyotrophic lateral sclerosisassociated SOD1 mutant proteins bind and aggregate with Bcl-2 in spinal cord mitochondria. Neuron 43, 19-30.

[39] Kirkinezos IG, Bacman SR, Hernandez D, Oca-Cossio J, Arias LJ, Perez-Pinzon MA, Bradley WG, Moraes CT (2005) Cytochrome $\mathrm{c}$ association with the inner mitochondrial membrane is impaired in the CNS of G93A-SOD1 mice. $J$ Neurosci $25,164-172$.

[40] Takeuchi H, Kobayashi Y, Ishigaki S, Doyu M, Sobue G (2002) Mitochondrial localization of mutant superoxide dismutase 1 triggers caspase-dependent cell death in a cellular model of familial amyotrophic lateral sclerosis. J Biol Chem 277, 50966-50972.

[41] Dal Canto MC, Gurney ME (1995) Neuropathological changes in two lines of mice carrying a transgene for mutant human $\mathrm{Cu}, \mathrm{Zn} \mathrm{SOD}$, and in mice overexpressing wild type human SOD: a model of familial amyotrophic lateral sclerosis (FALS). Brain Res 676, 25-40.

[42] Jaarsma D, Haasdijk ED, Grashorn JA, Hawkins R, van Duijn W, Verspaget HW, London J, Holstege JC (2000) Human $\mathrm{Cu} / \mathrm{Zn}$ superoxide dismutase (SOD1) overexpression in mice causes mitochondrial vacuolization, axonal degeneration, and premature motoneuron death and accelerates motoneuron disease in mice expressing a familial amyotrophic lateral sclerosis mutant SOD1. Neurobiol Dis 7, 623-643.

[43] Sasaki S, Iwata M (1996) Ultrastructural study of synapses in the anterior horn neurons of patients with amyotrophic lateral sclerosis. Neurosci Lett 204, 53-56.

[44] Hirano A, Nakano I, Kurland LT, Mulder DW, Holley PW, Saccomanno G (1984) Fine structural study of neurofibrillary changes in a family with amyotrophic lateral sclerosis. $J$ Neuropathol Exp Neurol 43, 471-480.

[45] Sotelo-Silveira JR, Lepanto P, Elizondo V, Horjales S, Palacios F, Martinez-Palma L, Marin M, Beckman JS, Barbeito L (2009) Axonal mitochondrial clusters containing mutant SOD1 in transgenic models of ALS. Antioxid Redox Signal 11, 1535-1545.

[46] Raimondi A, Mangolini A, Rizzardini M, Tartari S, Massari S, Bendotti C, Francolini M, Borgese N, Cantoni L, Pietrini G (2006) Cell culture models to investigate the selective vulnerability of motoneuronal mitochondria to familial ALSlinked G93ASOD1. Eur J Neurosci 24, 387-399.

[47] Menzies FM, Cookson MR, Taylor RW, Turnbull DM, Chrzanowska-Lightowlers ZM, Dong L, Figlewicz DA, Shaw PJ (2002) Mitochondrial dysfunction in a cell culture model of familial amyotrophic lateral sclerosis. Brain 125, 1522-1533.

[48] Higgins CM, Jung C, Xu Z (2003) ALS-associated mutant SOD1G93A causes mitochondrial vacuolation by expansion of the intermembrane space and by involvement of SOD1 aggregation and peroxisomes. BMC Neurosci 4, 16.

[49] Reiner A, Medina L, Figueredo-Cardenas G, Anfinson S (1995) Brainstem motoneuron pools that are selectively resistant in amyotrophic lateral sclerosis are preferentially enriched in parvalbumin: evidence from monkey brainstem for a calcium-mediated mechanism in sporadic ALS. Exp Neurol 131, 239-250.

[50] Damiano M, Starkov AA, Petri S, Kipiani K, Kiaei M, Mattiazzi M, Flint Beal M, Manfredi G (2006) Neural mitochondrial $\mathrm{Ca} 2+$ capacity impairment precedes the onset of motor symptoms in $\mathrm{G} 93 \mathrm{~A} \mathrm{Cu} / \mathrm{Zn}$-superoxide dismutase mutant mice. J Neurochem 96, 1349-1361.

[51] Jaiswal MK, Zech WD, Goos M, Leutbecher C, Ferri A, Zippelius A, Carri MT, Nau R, Keller BU (2009) Impairment of mitochondrial calcium handling in a mtSOD1 cell culture model of motoneuron disease. BMC Neurosci 10, 64 .

[52] Wang X, Schwarz TL (2009) The mechanism of Ca2+ -dependent regulation of kinesin-mediated mitochondrial motility. Cell 136, 163-174.

[53] Chang DT, Honick AS, Reynolds IJ (2006) Mitochondrial trafficking to synapses in cultured primary cortical neurons. J Neurosci 26, 7035-7045.

[54] Yi M, Weaver D, Hajnoczky G (2004) Control of mitochondrial motility and distribution by the calcium signal: a homeostatic circuit. J Cell Biol 167, 661-672.

[55] Guegan C, Vila M, Rosoklija G, Hays AP, Przedborski S (2001) Recruitment of the mitochondrial-dependent apoptotic pathway in amyotrophic lateral sclerosis. J Neurosci 21, 6569-6576.

[56] Vukosavic S, Dubois-Dauphin M, Romero N, Przedborski $S$ (1999) Bax and Bcl-2 interaction in a transgenic mouse model of familial amyotrophic lateral sclerosis. J Neurochem 73, 2460-2468.

[57] Ishigaki S, Liang Y, Yamamoto M, Niwa J, Ando Y, Yoshihara T, Takeuchi H, Doyu M, Sobue G (2002) X-Linked inhibitor of apoptosis protein is involved in mutant SOD1mediated neuronal degeneration. J Neurochem 82, 576-584.

[58] Li M, Ona VO, Guegan C, Chen M, Jackson-Lewis V, Andrews LJ, Olszewski AJ, Stieg PE, Lee JP, Przedborski S, Friedlander RM (2000) Functional role of caspase-1 and 
caspase-3 in an ALS transgenic mouse model. Science $\mathbf{2 8 8}$, 335-339.

[59] Pasinelli P, Borchelt DR, Houseweart MK, Cleveland DW, Brown RH, Jr. (1998) Caspase-1 is activated in neural cells and tissue with amyotrophic lateral sclerosis-associated mutations in copper-zinc superoxide dismutase. Proc Natl Acad Sci U S A 95, 15763-15768.

[60] Pasinelli P, Houseweart MK, Brown RH, Jr., Cleveland DW (2000) Caspase-1 and -3 are sequentially activated in motor neuron death in $\mathrm{Cu}, \mathrm{Zn}$ superoxide dismutase-mediated familial amyotrophic lateral sclerosis. Proc Natl Acad Sci U S A 97, 13901-13906.

[61] Zhu S, Stavrovskaya IG, Drozda M, Kim BY, Ona V, Li M, Sarang S, Liu AS, Hartley DM, Wu DC, Gullans S, Ferrante RJ, Przedborski S, Kristal BS, Friedlander RM (2002) Minocycline inhibits cytochrome c release and delays progression of amyotrophic lateral sclerosis in mice. Nature 417, 74-78.

[62] Kostic V, Jackson-Lewis V, de Bilbao F, Dubois-Dauphin M, Przedborski S (1997) Bcl-2: prolonging life in a transgenic mouse model of familial amyotrophic lateral sclerosis. Science 277, 559-562.

[63] Martin LJ, Gertz B, Pan Y, Price AC, Molkentin JD, Chang Q (2009) The mitochondrial permeability transition pore in motor neurons: Involvement in the pathobiology of ALS mice. Exp Neurol 218, 333-346.

[64] Gordon PH, Moore DH, Miller RG, Florence JM, Verheijde JL, Doorish C, Hilton JF, Spitalny GM, MacArthur RB, Mitsumoto H, Neville HE, Boylan K, Mozaffar T, Belsh JM, Ravits J, Bedlack RS, Graves MC, McCluskey LF, Barohn RJ, Tandan R (2007) Efficacy of minocycline in patients with amyotrophic lateral sclerosis: a phase III randomised trial. Lancet Neurol 6, 1045-1053.

[65] Gould TW, Buss RR, Vinsant S, Prevette D, Sun W, Knudson CM, Milligan CE, Oppenheim RW (2006) Complete dissociation of motor neuron death from motor dysfunction by Bax deletion in a mouse model of ALS. J Neurosci 26, 8774-8786.

[66] Fischer LR, Culver DG, Tennant P, Davis AA, Wang M, Castellano-Sanchez A, Khan J, Polak MA, Glass JD (2004) Amyotrophic lateral sclerosis is a distal axonopathy: evidence in mice and man. Exp Neurol 185, 232-240.

[67] Williamson TL, Cleveland DW (1999) Slowing of axonal transport is a very early event in the toxicity of ALS-linked SOD1 mutants to motor neurons. Nat Neurosci 2, 50-56.

[68] Zhang B, Tu P, Abtahian F, Trojanowski JQ, Lee VM (1997) Neurofilaments and orthograde transport are reduced in ventral root axons of transgenic mice that express human SOD1 with a G93A mutation. J Cell Biol 139, 1307-1315.

[69] Reid E, Kloos M, Ashley-Koch A, Hughes L, Bevan S, Svenson IK, Graham FL, Gaskell PC, Dearlove A, PericakVance MA, Rubinsztein DC, Marchuk DA (2002) A kinesin heavy chain (KIF5A) mutation in hereditary spastic paraplegia (SPG10). Am J Hum Genet 71, 1189-1194.

[70] Puls I, Jonnakuty C, LaMonte BH, Holzbaur EL, Tokito M, Mann E, Floeter MK, Bidus K, Drayna D, Oh SJ, Brown RH, Jr., Ludlow CL, Fischbeck KH (2003) Mutant dynactin in motor neuron disease. Nat Genet 33, 455-456.

[71] LaMonte BH, Wallace KE, Holloway BA, Shelly SS, Ascano J, Tokito M, Van Winkle T, Howland DS, Holzbaur EL (2002) Disruption of dynein/dynactin inhibits axonal transport in motor neurons causing late-onset progressive degeneration. Neuron 34, 715-727.

[72] Hafezparast M, Klocke R, Ruhrberg C, Marquardt A, Ahmad-Annuar A, Bowen S, Lalli G, Witherden AS, Hum- merich $\mathrm{H}$, Nicholson S, Morgan PJ, Oozageer R, Priestley JV, Averill S, King VR, Ball S, Peters J, Toda T, Yamamoto A, Hiraoka Y, Augustin M, Korthaus D, Wattler S, Wabnitz P, Dickneite C, Lampel S, Boehme F, Peraus G, Popp A, Rudelius M, Schlegel J, Fuchs H, Hrabe de Angelis M, Schiavo G, Shima DT, Russ AP, Stumm G, Martin JE, Fisher EM (2003) Mutations in dynein link motor neuron degeneration to defects in retrograde transport. Science 300, 808-812.

[73] Chen XJ, Levedakou EN, Millen KJ, Wollmann RL, Soliven B, Popko B (2007) Proprioceptive sensory neuropathy in mice with a mutation in the cytoplasmic Dynein heavy chain 1 gene. J Neurosci 27, 14515-14524.

[74] Lai C, Lin X, Chandran J, Shim H, Yang WJ, Cai H (2007) The G59S mutation in p150(glued) causes dysfunction of dynactin in mice. J Neurosci 27, 13982-13990.

[75] Teuling E, van Dis V, Wulf PS, Haasdijk ED, Akhmanova A, Hoogenraad CC, Jaarsma D (2008) A novel mouse model with impaired dynein/dynactin function develops amyotrophic lateral sclerosis (ALS)-like features in motor neurons and improves lifespan in SOD1-ALS mice. Hum Mol Genet 17, 2849-2862.

[76] Laird FM, Farah MH, Ackerley S, Hoke A, Maragakis N, Rothstein JD, Griffin J, Price DL, Martin LJ, Wong PC (2008) Motor neuron disease occurring in a mutant dynactin mouse model is characterized by defects in vesicular trafficking. $J$ Neurosci 28, 1997-2005.

[77] Breuer AC, Lynn MP, Atkinson MB, Chou SM, Wilbourn AJ, Marks KE, Culver JE, Fleegler EJ (1987) Fast axonal transport in amyotrophic lateral sclerosis: an intra-axonal organelle traffic analysis. Neurology 37, 738-748.

[78] Breuer AC, Atkinson MB (1988) Fast axonal transport alterations in amyotrophic lateral sclerosis (ALS) and in parathyroid hormone (PTH)-treated axons. Cell Motil Cytoskeleton 10, 321-330.

[79] Collard JF, Cote F, Julien JP (1995) Defective axonal transport in a transgenic mouse model of amyotrophic lateral sclerosis. Nature 375, 61-64.

[80] Sasaki S, Iwata M (1996) Impairment of fast axonal transport in the proximal axons of anterior horn neurons in amyotrophic lateral sclerosis. Neurology 47, 535-540.

[81] Ligon LA, LaMonte BH, Wallace KE, Weber N, Kalb RG, Holzbaur EL (2005) Mutant superoxide dismutase disrupts cytoplasmic dynein in motor neurons. Neuroreport 16, 533536.

[82] Parkhouse WS, Cunningham L, McFee I, Miller JM, Whitney D, Pelech SL, Krieger C (2008) Neuromuscular dysfunction in the mutant superoxide dismutase mouse model of amyotrophic lateral sclerosis. Amyotroph Lateral Scler $\mathbf{9}$, 24-34.

[83] Kieran D, Hafezparast M, Bohnert S, Dick JR, Martin J, Schiavo G, Fisher EM, Greensmith L (2005) A mutation in dynein rescues axonal transport defects and extends the life span of ALS mice. J Cell Biol 169, 561-567.

[84] Teuchert M, Fischer D, Schwalenstoecker B, Habisch HJ, Bockers TM, Ludolph AC (2006) A dynein mutation attenuates motor neuron degeneration in SOD1(G93A) mice. Exp Neurol 198, 271-274.

[85] Zhang F, Strom AL, Fukada K, Lee S, Hayward LJ, Zhu H (2007) Interaction between familial amyotrophic lateral sclerosis (ALS)-linked SOD1 mutants and the dynein complex. J Biol Chem 282, 16691-16699.

[86] Strom AL, Shi P, Zhang F, Gal J, Kilty R, Hayward LJ, Zhu $H$ (2008) Interaction of amyotrophic lateral sclerosis (ALS)related mutant copper-zinc superoxide dismutase with the 
dynein-dynactin complex contributes to inclusion formation. J Biol Chem 283, 22795-22805.

[87] Tateno M, Kato S, Sakurai T, Nukina N, Takahashi R, Araki T (2009) Mutant SOD1 impairs axonal transport of choline acetyltransferase and acetylcholine release by sequestering KAP3. Hum Mol Genet 18, 942-955.

[88] Landers JE, Melki J, Meininger V, Glass JD, van den Berg LH, van Es MA, Sapp PC, van Vught PW, McKenna-Yasek DM, Blauw HM, Cho TJ, Polak M, Shi L, Wills AM, Broom WJ, Ticozzi N, Silani V, Ozoguz A, Rodriguez-Leyva I, Veldink JH, Ivinson AJ, Saris CG, Hosler BA, Barnes-Nessa A, Couture N, Wokke JH, Kwiatkowski TJ, Jr., Ophoff RA, Cronin S, Hardiman O, Diekstra FP, Leigh PN, Shaw CE, Simpson CL, Hansen VK, Powell JF, Corcia P, Salachas F, Heath S, Galan P, Georges F, Horvitz HR, Lathrop M, Purcell S, Al-Chalabi A, Brown RH, Jr. (2009) Reduced expression of the Kinesin-Associated Protein 3 (KIFAP3) gene increases survival in sporadic amyotrophic lateral sclerosis. Proc Natl Acad Sci U S A 106, 9004-9009.

[89] Dupuis L, de Tapia M, Rene F, Lutz-Bucher B, Gordon JW, Mercken L, Pradier L, Loeffler JP (2000) Differential screening of mutated SOD1 transgenic mice reveals early up-regulation of a fast axonal transport component in spinal cord motor neurons. Neurobiol Dis 7, 274-285.

[90] Perlson E, Jeong GB, Ross JL, Dixit R, Wallace KE, Kalb RG, Holzbaur EL (2009) A switch in retrograde signaling from survival to stress in rapid-onset neurodegeneration. $J$ Neurosci 29, 9903-9917.

[91] Tortarolo M, Veglianese P, Calvaresi N, Botturi A, Rossi C, Giorgini A, Migheli A, Bendotti C (2003) Persistent activation of p38 mitogen-activated protein kinase in a mouse model of familial amyotrophic lateral sclerosis correlates with disease progression. Mol Cell Neurosci 23, 180-192.

[92] Ackerley S, Grierson AJ, Banner S, Perkinton MS, Brownlees J, Byers HL, Ward M, Thornhill P, Hussain K, Waby JS, Anderton BH, Cooper JD, Dingwall C, Leigh PN, Shaw CE, Miller CC (2004) p38alpha stress-activated protein kinase phosphorylates neurofilaments and is associated with neurofilament pathology in amyotrophic lateral sclerosis. Mol Cell Neurosci 26, 354-364.

[93] De Vos K, Severin F, Van Herreweghe F, Vancompernolle K, Goossens V, Hyman A, Grooten J (2000) Tumor necrosis factor induces hyperphosphorylation of kinesin light chain and inhibits kinesin-mediated transport of mitochondria. $J$ Cell Biol 149, 1207-1214.

[94] Morfini G, Pigino G, Szebenyi G, You Y, Pollema S, Brady ST (2006) JNK mediates pathogenic effects of polyglutamineexpanded androgen receptor on fast axonal transport. Nat Neurosci 9, 907-916.

[95] Hollenbeck PJ, Saxton WM (2005) The axonal transport of mitochondria. J Cell Sci 118, 5411-5419.

[96] Goldstein AY, Wang X, Schwarz TL (2008) Axonal transport and the delivery of pre-synaptic components. Curr Opin Neurobiol 18, 495-503.

[97] Shepherd GM, Harris KM (1998) Three-dimensional structure and composition of CA3->CA1 axons in rat hippocampal slices: implications for presynaptic connectivity and compartmentalization. J Neurosci 18, 8300-8310.

[98] Rowland KC, Irby NK, Spirou GA (2000) Specialized synapse-associated structures within the calyx of Held. $J$ Neurosci 20, 9135-9144.

[99] Li Z, Okamoto K, Hayashi Y, Sheng M (2004) The importance of dendritic mitochondria in the morphogenesis and plasticity of spines and synapses. Cell 119, 873-887.
[100] Tanaka Y, Kanai Y, Okada Y, Nonaka S, Takeda S, Harada A, Hirokawa N (1998) Targeted disruption of mouse conventional kinesin heavy chain, kif5B, results in abnormal perinuclear clustering of mitochondria. Cell 93, 1147-1158.

[101] Nangaku M, Sato-Yoshitake R, Okada Y, Noda Y, Takemura R, Yamazaki H, Hirokawa N (1994) KIF1B, a novel microtubule plus end-directed monomeric motor protein for transport of mitochondria. Cell 79, 1209-1220.

[102] Zhang Y, Oko R, van der Hoorn FA (2004) Rat kinesin light chain 3 associates with spermatid mitochondria. Dev Biol 275, 23-33.

[103] Varadi A, Johnson-Cadwell LI, Cirulli V, Yoon Y, Allan VJ, Rutter GA (2004) Cytoplasmic dynein regulates the subcellular distribution of mitochondria by controlling the recruitment of the fission factor dynamin-related protein-1. J Cell Sci 117, 4389-4400.

[104] Glater EE, Megeath LJ, Stowers RS, Schwarz TL (2006) Axonal transport of mitochondria requires milton to recruit kinesin heavy chain and is light chain independent. $J$ Cell Biol 173, 545-557.

[105] Fransson S, Ruusala A, Aspenstrom P (2006) The atypical Rho GTPases Miro-1 and Miro-2 have essential roles in mitochondrial trafficking. Biochem Biophys Res Commun 344, 500-510.

[106] Guo X, Macleod GT, Wellington A, Hu F, Panchumarthi S, Schoenfield M, Marin L, Charlton MP, Atwood HL, Zinsmaier KE (2005) The GTPase dMiro is required for axonal transport of mitochondria to Drosophila synapses. Neuron 47, 379-393.

[107] Fransson A, Ruusala A, Aspenstrom P (2003) Atypical Rho GTPases have roles in mitochondrial homeostasis and apoptosis. J Biol Chem 278, 6495-6502.

[108] Beck M, Brickley K, Wilkinson HL, Sharma S, Smith M, Chazot PL, Pollard S, Stephenson FA (2002) Identification, molecular cloning, and characterization of a novel GABAA receptor-associated protein, GRIF-1. J Biol Chem 277, 30079-30090.

[109] Iyer SP, Akimoto Y, Hart GW (2003) Identification and cloning of a novel family of coiled-coil domain proteins that interact with O-GlcNAc transferase. J Biol Chem 278, 53995409

[110] Brickley K, Smith MJ, Beck M, Stephenson FA (2005) GRIF1 and OIP106, members of a novel gene family of coiledcoil domain proteins: association in vivo and in vitro with kinesin. J Biol Chem 280, 14723-14732.

[111] Chada SR, Hollenbeck PJ (2004) Nerve growth factor signaling regulates motility and docking of axonal mitochondria. Curr Biol 14, 1272-1276.

[112] Chada SR, Hollenbeck PJ (2003) Mitochondrial movement and positioning in axons: the role of growth factor signaling. J Exp Biol 206, 1985-1992.

[113] Orr AL, Li S, Wang CE, Li H, Wang J, Rong J, Xu X, Mastroberardino PG, Greenamyre JT, Li XJ (2008) N-terminal mutant huntingtin associates with mitochondria and impairs mitochondrial trafficking. $J$ Neurosci 28, 2783-2792.

[114] Weihofen A, Thomas KJ, Ostaszewski BL, Cookson MR, Selkoe DJ (2009) Pink1 forms a multiprotein complex with Miro and Milton, linking Pink1 function to mitochondrial trafficking. Biochemistry 48, 2045-2052.

[115] De Vos KJ, Chapman AL, Tennant ME, Manser C, Tudor EL, Lau KF, Brownlees J, Ackerley S, Shaw PJ, McLoughlin DM, Shaw CE, Leigh PN, Miller CC, Grierson AJ (2007) Familial amyotrophic lateral sclerosis-linked SOD1 mutants perturb fast axonal transport to reduce axonal mitochondria 
content. Hum Mol Genet 16, 2720-2728.

[116] Magrane J, Manfredi G (2009) Mitochondrial function, morphology, and axonal transport in amyotrophic lateral sclerosis. Antioxid Redox Signal 11, 1615-1626.

[117] Magrane J, Hervias I, Henning MS, Damiano M, Kawamata H, Manfredi G (2009) Mutant SOD1 in neuronal mitochondria causes toxicity and mitochondrial dynamics abnormalities. Hum Mol Genet 18, 4552-4564.

[118] Shi P, Gal J, Kwinter DM, Liu X, Zhu H (2010) Mitochondrial dysfunction in amyotrophic lateral sclerosis. Biochim Biophys Acta 1802, 45-51.

[119] Miller KE, Sheetz MP (2004) Axonal mitochondrial transport and potential are correlated. J Cell Sci 117, 2791-2804.

[120] Dewil M, dela Cruz VF, Van Den Bosch L, Robberecht W (2007) Inhibition of p38 mitogen activated protein kinase activation and mutant SOD1(G93A)-induced motor neuron death. Neurobiol Dis 26, 332-341.

[121] Morfini G, Pigino G, Opalach K, Serulle Y, Moreira JE, Sugimori M, Llinas RR, Brady ST (2007) 1-Methyl-4phenylpyridinium affects fast axonal transport by activation of caspase and protein kinase C. Proc Natl Acad Sci U S A 104, 2442-2447.

[122] Shibata N, Kawaguchi-Niida M, Yamamoto T, Toi S, Hirano A, Kobayashi M (2008) Effects of the PPARgamma activator pioglitazone on p38 MAP kinase and IkappaBalpha in the spinal cord of a transgenic mouse model of amyotrophic lateral sclerosis. Neuropathology 28, 387-398.

[123] Morfini GA, You YM, Pollema SL, Kaminska A, Liu K, Yoshioka K, Bjorkblom B, Coffey ET, Bagnato C, Han D, Huang CF, Banker G, Pigino G, Brady ST (2009) Pathogenic huntingtin inhibits fast axonal transport by activating JNK3 and phosphorylating kinesin. Nat Neurosci 12, 864-871.

[124] Pigino G, Morfini G, Atagi Y, Deshpande A, Yu C, Jungbauer L, LaDu M, Busciglio J, Brady S (2009) Disruption of fast axonal transport is a pathogenic mechanism for intraneuronal amyloid beta. Proc Natl Acad Sci U S A 106, 5907-5912.

[125] Chan DC (2006) Mitochondrial fusion and fission in mammals. Annu Rev Cell Dev Biol 22, 79-99.

[126] Chen H, Chomyn A, Chan DC (2005) Disruption of fusion results in mitochondrial heterogeneity and dysfunction. J Biol Chem 280, 26185-26192.

[127] Zuchner S, Mersiyanova IV, Muglia M, Bissar-Tadmouri N, Rochelle J, Dadali EL, Zappia M, Nelis E, Patitucci A, Senderek J, Parman Y, Evgrafov O, Jonghe PD, Takahashi Y, Tsuji S, Pericak-Vance MA, Quattrone A, Battaloglu E, Polyakov AV, Timmerman V, Schroder JM, Vance JM (2004) Mutations in the mitochondrial GTPase mitofusin 2 cause Charcot-Marie-Tooth neuropathy type 2A. Nat Genet 36, 449-451.

[128] Alexander C, Votruba M, Pesch UE, Thiselton DL, Mayer S, Moore A, Rodriguez M, Kellner U, Leo-Kottler B, Auburger G, Bhattacharya SS, Wissinger B (2000) OPA1, encoding a dynamin-related GTPase, is mutated in autosomal dominant optic atrophy linked to chromosome 3q28. Nat Genet 26, 211-215.

[129] Smirnova E, Griparic L, Shurland DL, van der Bliek AM (2001) Dynamin-related protein Drp1 is required for mitochondrial division in mammalian cells. Mol Biol Cell $\mathbf{1 2}$ 2245-2256.

[130] James DI, Parone PA, Mattenberger Y, Martinou JC (2003) hFis1, a novel component of the mammalian mitochondrial fission machinery. J Biol Chem 278, 36373-36379.

[131] Sotelo-Silveira JR, Lepanto P, Elizondo MV, Horjales S, Palacios F, Martinez Palma L, Marin M, Beckman JS, Barbeito
L (2009) Axonal mitochondrial clusters containing mutant SOD1 in transgenic models of ALS. Antioxid Redox Signal 11, 1535-1545.

[132] Magrane J, Manfredi G (2009) Mitochondrial function, morphology, and axonal transport in amyotrophic lateral sclerosis. Antioxid Redox Signal 11, 1615-1626.

[133] Wang X, Su B, Fujioka H, Zhu X (2008) Dynamin-like protein 1 reduction underlies mitochondrial morphology and distribution abnormalities in fibroblasts from sporadic Alzheimer's disease patients. Am J Pathol 173, 470-482.

[134] Wang X, Su B, Siedlak SL, Moreira PI, Fujioka H, Wang Y, Casadesus G, Zhu X (2008) Amyloid-beta overproduction causes abnormal mitochondrial dynamics via differential modulation of mitochondrial fission/fusion proteins. Proc Natl Acad Sci U S A 105, 19318-19323.

[135] Wang X, Su B, Lee HG, Li X, Perry G, Smith MA, Zhu X (2009) Impaired balance of mitochondrial fission and fusion in Alzheimer's disease. J Neurosci 29, 9090-9103.

[136] Bossy-Wetzel E, Barsoum MJ, Godzik A, Schwarzenbacher R, Lipton SA (2003) Mitochondrial fission in apoptosis, neurodegeneration and aging. Curr Opin Cell Biol 15, 706-716.

[137] Karbowski M, Arnoult D, Chen H, Chan DC, Smith CL, Youle RJ (2004) Quantitation of mitochondrial dynamics by photolabeling of individual organelles shows that mitochondrial fusion is blocked during the Bax activation phase of apoptosis. J Cell Biol 164, 493-499.

[138] Carriedo SG, Sensi SL, Yin HZ, Weiss JH (2000) AMPA exposures induce mitochondrial $\mathrm{Ca}(2+)$ overload and ROS generation in spinal motor neurons in vitro. J Neurosci $\mathbf{2 0}$, 240-250.

[139] Novak I, Kirkin V, McEwan DG, Zhang J, Wild P, Rozenknop A, Rogov V, Lohr F, Popovic D, Occhipinti A, Reichert AS, Terzic J, Dotsch V, Ney PA, Dikic I (2010) Nix is a selective autophagy receptor for mitochondrial clearance. EMBO Rep 11, 45-51.

[140] Geisler S, Holmstrom KM, Skujat D, Fiesel FC, Rothfuss OC, Kahle PJ, Springer W (2010) PINK1/Parkin-mediated mitophagy is dependent on VDAC1 and p62/SQSTM1. Nat Cell Biol 12, 119-131.

[141] Vives-Bauza C, Zhou C, Huang Y, Cui M, de Vries RL, Kim J, May J, Tocilescu MA, Liu W, Ko HS, Magrane J, Moore DJ, Dawson VL, Grailhe R, Dawson TM, Li C, Tieu K, Przedborski S (2010) PINK1-dependent recruitment of Parkin to mitochondria in mitophagy. Proc Natl Acad Sci U S A 107, 378-383.

[142] Park KH, Vincent I (2008) Presymptomatic biochemical changes in hindlimb muscle of G93A human $\mathrm{Cu} / \mathrm{Zn}$ superoxide dismutase 1 transgenic mouse model of amyotrophic lateral sclerosis. Biochim Biophys Acta 1782, 462-468.

[143] Gordon T, Ly V, Hegedus J, Tyreman N (2009) Early detection of denervated muscle fibers in hindlimb muscles after sciatic nerve transection in wild type mice and in the G93A mouse model of amyotrophic lateral sclerosis. Neurol Res 31, 28-42.

[144] Lemmens R, Van Hoecke A, Hersmus N, Geelen V, D'Hollander I, Thijs V, Van Den Bosch L, Carmeliet P, Robberecht W (2007) Overexpression of mutant superoxide dismutase 1 causes a motor axonopathy in the zebrafish. Hum Mol Genet 16, 2359-2365.

[145] Dupuis L, Gonzalez de Aguilar J-L, Echaniz-Laguna A, Eschbach J, Rene Fdr, Oudart H, Halter B, Huze C, Schaeffer L, Bouillaud Fdr, Loeffler J-P (2009) Muscle mitochondrial uncoupling dismantles neuromuscular junction and triggers distal degeneration of motor neurons. PLoS ONE 4, e5390. 
[146] Ilieva H, Polymenidou M, Cleveland DW (2009) Non-cell autonomous toxicity in neurodegenerative disorders: ALS and beyond. J Cell Biol 187, 761-772.

[147] Pramatarova A, Laganiere J, Roussel J, Brisebois K, Rouleau GA (2001) Neuron-specific expression of mutant superoxide dismutase 1 in transgenic mice does not lead to motor impairment. J Neurosci 21, 3369-3374.

[148] Lino MM, Schneider C, Caroni P (2002) Accumulation of SOD1 mutants in postnatal motoneurons does not cause motoneuron pathology or motoneuron disease. J Neurosci 22 4825-4832.

[149] Clement AM, Nguyen MD, Roberts EA, Garcia ML, Boillee S, Rule M, McMahon AP, Doucette W, Siwek D, Ferrante RJ, Brown RH, Jr., Julien JP, Goldstein LS, Cleveland DW (2003) Wild-type nonneuronal cells extend survival of SOD1 mutant motor neurons in ALS mice. Science 302, 113-117.

[150] Boillee S, Yamanaka K, Lobsiger CS, Copeland NG, Jenkin NA, Kassiotis G, Kollias G, Cleveland DW (2006) Onset and progression in inherited ALS determined by motor neurons and microglia. Science 312, 1389-1392.

[151] Yamanaka K, Boillee S, Roberts EA, Garcia ML, McAlonisDownes M, Mikse OR, Cleveland DW, Goldstein LS (2008) Mutant SOD1 in cell types other than motor neurons and oligodendrocytes accelerates onset of disease in ALS mice. Proc Natl Acad Sci U S A 105, 7594-7599.

[152] Yamanaka K, Chun SJ, Boillee S, Fujimori-Tonou N, Yamashita H, Gutmann DH, Takahashi R, Misawa H, Cleveland DW (2008) Astrocytes as determinants of disease progression in inherited amyotrophic lateral sclerosis. Nat Neurosci 11, 251-253.
[153] Lobsiger CS, Boillee S, McAlonis-Downes M, Khan AM, Feltri ML, Yamanaka K, Cleveland DW (2009) Schwann cells expressing dismutase active mutant SOD1 unexpectedly slow disease progression in ALS mice. Proc Natl Acad Sci U S A 106, 4465-4470.

[154] Nagai M, Re DB, Nagata T, Chalazonitis A, Jessell TM, Wichterle H, Przedborski S (2007) Astrocytes expressing ALS-linked mutated SOD1 release factors selectively toxic to motor neurons. Nat Neurosci 10, 615-622.

[155] Di Giorgio FP, Carrasco MA, Siao MC, Maniatis T, Eggan K (2007) Non-cell autonomous effect of glia on motor neurons in an embryonic stem cell-based ALS model. Nat Neurosci 10, 608-614.

[156] Di Giorgio FP, Boulting GL, Bobrowicz S, Eggan KC (2008) Human embryonic stem cell-derived motor neurons are sensitive to the toxic effect of glial cells carrying an ALS-causing mutation. Cell Stem Cell 3, 637-648.

[157] Jaarsma D, Teuling E, Haasdijk ED, De Zeeuw CI, Hoogenraad CC (2008) Neuron-specific expression of mutant superoxide dismutase is sufficient to induce amyotrophic lateral sclerosis in transgenic mice. J Neurosci 28, 2075-2088.

[158] Dobrowolny G, Aucello M, Rizzuto E, Beccafico S, Mammucari C, Boncompagni S, Belia S, Wannenes F, Nicoletti C, Del Prete Z, Rosenthal N, Molinaro M, Protasi F, Fano G, Sandri M, Musaro A (2008) Skeletal muscle is a primary target of SOD1G93A-mediated toxicity. Cell Metab 8, 425436.

[159] Wong M, Martin LJ (2010) Skeletal muscle-restricted expression of human SOD1 causes motor neuron degeneration in transgenic mice. Hum Mol Genet 19, 2284-2302. 